\title{
FAKTOR-FAKTOR YANG BERHUBUNGAN DENGAN PEMILIHAN METODE KONTRASEPSI PADA WANITA USIA SUBUR DI WILAYAH KERJA PUSKESMAS RANOTANA WERU
}

\author{
Zakiah Bakri \\ Rina Kundre \\ Hendro Bidjuni \\ Program Studi Ilmu Keperawatan Fakultas Kedokteran \\ Universitas Sam Ratulangi \\ Email: zakiabakri@gmail.com
}

\begin{abstract}
The government's program called Family Planning runs to control the growth of the population in Indonesia. The application of this program is by using contraception which has several types such as pills, injections, tubectomy, etc. Research objective to find out the relation between knowledge, partner's support, and the role of Field Officer of Family Planning (Petugas Lapangan Keluarga Berencana - PLKB) regarding to the selection of hormonal contraceptive methods. Design is using quantitative research with the Cross-sectional and correlational method which actually study the relatio or affection between two or more variables at the same time. Sample there are 44 childbearing women who have been sampled by using Slovin's formula. Result by using the Chi Square experiment with $\alpha=0.05$ obtained: knowledge $(p=0.036)$, partner's support $(p=0.030)$, the role of PLKB $(p=0.317)$. Conclusion there is a relation between the knowledge and partner's support regarding to the selection of hormonal contraceptive methods
\end{abstract}

Keyword : Hormonal Contraceptive Methods, Childbearing Age Women

\begin{abstract}
Abstrak: Keluarga Berencana merupakan suatu program pemerintah yang secara khusus bertanggung jawab terhadap pengendalian pertumbuhan penduduk di Indonesia. Program tersebut dapat dilakukan dengan penggunaan alat kontrasepsi seperti pil, suntik, tubektomi, dan sebagainya. Tujuan penelitian mengetahui hubungan pengetahuan, dukungan suami, dan peran Petugas Lapangan Keluarga Berencana (PLKB) terhadap pemilihan metode kontrasepsi hormonal. Desain Penelitian ini menggunakan jenis penelitian kuantitatif dengan metode Cross Sectional korelasional yaitu penelitian yang bertujuan untuk mengetahui hubungan atau pengaruh antara dua atau lebih variabel penelitian yang diukur dalam waktu bersamaan. Sampel pada penelitian ini sebanyak 44 wanita usia subur dengan tehnik pengambilan sampel menggunakan rumus Slovin. Hasil Penelitian menggunakan uji Chi Square dengan $\alpha=0.05$ diperoleh pengetahuan $(p=0.036)$, dukungan suami $(p=0.030)$ peran PLKB $(p=0.317)$. Kesimpulan yaitu ada hubungan pengetahuan dan dukungan suami dengan pemilihan metode kontrasepsi hormonal, serta tidak ada hubungan peran PLKB dengan pemilihan metode kontrasepsi hormonal.
\end{abstract}

Kata kunci : Metode Kontrasepsi Hormonal, Wanita Usia Subur 


\section{PENDAHULUAN}

Indonesia termasuk negara dengan jumlah penduduk yang tinggi. Indonesia merupakan negara keempat dengan jumlah penduduk terbanyak di dunia. Jumlah penduduk Indonesia dari tahun ke tahun terus meningkat. Menurut data Badan Pusat Statistik (BPS) tahun 2017, tercatat jumlah penduduk di Indonesia pada tahun 2015 sebanyak 258,2 juta jiwa, tahun 2016 sebanyak 261,1 juta jiwa, dan tahun 2017 sebanyak 264 juta jiwa. (Badan Pusat Statistik Indonesia, 2017).

Upaya pemerintah dalam menekan tingginya laju pertumbuhan di Indonesia yaitu dengan membentuk sebuah badan yang secara spesifik dan khusus bertanggung jawab terhadap pengendalian pertumbuhan penduduk di Indonesia, yaitu Badan Koordinasi Keluarga Berencana Nasional (BKKBN). KB merupakan suatu program pemerintah yang dirancang untuk menyeimbangkan antara kebutuhan dan jumlah penduduk. Perencanaan jumlah penduduk tersebut dapat dilakukan dengan penggunaan alat-alat kontrasepsi atau penanggulangan kelahiran seperti kontrasepsi pil, suntik, implant, tubektomi, dan sebagainya. (Irianto Koes, 2014).

\section{Data Survey Sosial Ekonomi} Nasional (SUSENAS) tahun 2015 menggambarkan bahwa sebagian besar Pasangan Usia Subur (PUS) peserta KB di Indonesia masih mengandalkan kontrasepsi hormonal dengan persentase tertinggi yaitu KB Suntik $(59,57 \%)$ dan pil $(20,71 \%)$, tetapi KB susuk (6,21\%). (Susenas, 2015). Di Sulawesi Utara, tercatat jumlah Pasangan Usia Subur (PUS) menurut metode kontrasepsi tahun 2016 sebanyak 657.068 PUS, dengan penggunaan kontrasepsi terbanyak yaitu metode kontrasepsi hormonal. (Badan Pusat Statistik Sulawesi Utara, 2016).

Pilihan jenis alat kontrasepsi di Indonesia umumnya masih terarah pada metode kontrasepsi hormonal seperti suntik, pil dan implan. Sementara kebijakan pemerintah terhadap program KB lebih mengarah pada penggunaan kontrasepsi non hormonal seperti IUD, tubektomi, dan vasektomi. Di Puskesmas Ranotana Weru, saat dilakukan pengkajian rata-rata pengguna akseptor KB hanya metode kontrasepsi hormonal. Data kunjungan akseptor KB yang di peroleh di Puskesmas Ranotana Weru pada bulan Juni-Agustus tahun 2018 sebanyak 149 wanita usia subur (WUS) yang tercatat secara keseluruhan memilih metode kontrasepsi hormonal yang terdiri dari 14 akseptor KB pil, 122 akseptor KB Suntik 3 bulan, 11 akseptor KB suntik 1 bulan, dan 2 akseptor KB implan. Sementara hasil wawancara dengan salah satu petugas Puskesmas Ranotana Weru, didapatkan bahwa ketersediaan metode kontrasepsi yang ada di Puskesmas Ranotana Weru bukan hanya alat kontrasepsi hormonal, tetapi alat kontrasepsi dalam rahim (AKRD) yaitu IUD juga tersedia, namun tidak dengan kontrasepsi mantap seperti MOW dan MOP. (Profil Puskesmas Ranotana, 2018)

$$
\text { Pemilihan dan penggunaan }
$$
kontrasepsi pada WUS di wilayah kerja Puskesmas Ranotana ini masih belum berdasarkan atas pilihan yang rasional. Hal ini berkaitan dengan ketidaksesuaian tujuan kontrasepsi. Menurut Hartanto (2010), dalam mencapai sasaran guna mencapai tujuan ini, pelayanan kontrasepsi dibagi menjadi 3 fase, yaitu fase menunda kehamilan untuk umur dibawah 20 tahun dengan prioritas alat kontrasepsi yang digunakan yaitu kontrasepsi pil karena peserta KB yang masih muda, fase menjarangkan kehamilan untuk wanita usia 20-35 tahun, dengan pilihan utama IUD setelah anak pertama lahir karena dapat dipakai 2-4 tahun, dan fase mengakhiri kehamilan, dengan periode umur istri diatas 35 tahun, dengan pilihan utama adalah kontrasepsi mantap karena pada masa tua kelainan seperti penyakit jantung, hipertensi, keganasan dan metabolik biasanya meningkat sehingga sebaiknya tidak memberikan cara kontrasepsi yang menambah kelainan tersebut.

Ketidaksesuaian tujuan kontrasepsi ini tentu berhubungan dengan petugas yang 
seharusnya mampu menjelaskan serta memberikan informasi terkait pemilihan alat kontrasepsi. Pengetahuan yang diperoleh dapat dijadikan bahan pertimbangan dalam pengambilan keputusan. Selain peran petugas kesehatan, suami perlu memiliki keterlibatan dalam pengambilan keputusan mengenai alat kontrasepsi yang akan digunakan. Hal ini terkait dengan tanggung jawab suami sebagai pemberi nafkah, termasuk dalam membiayai segala kebutuhan istri, tidak terkecuali dengan biaya pemasangan alat kontrasepsi. Berdasarkan latar belakang tersebut, peneliti tertarik untuk melakukan penelitian lebih lanjut mengenai faktorfaktor yang berhubungan dengan pemilihan metode kontrasepsi hormonal pada wanita usia subur di wilayah kerja Puskesmas Ranotana Weru.

\section{METODE PENELITIAN}

Penelitian ini menggunakan jenis penelitian kuantitatif dengan metode Cross Sectional korelasional, yaitu penelitian yang bertujuan untuk mengetahui hubungan atau pengaruh antara dua atau lebih variabel penelitian dengan pendekatan Cross Sectional yaitu penelitian yang diukur dalam waktu bersamaan. (Siswanto, Susila \& Suyanto, 2016). Penelitian ini telah dilaksanakan di Puskesmas Ranotana Weru Kota Manado pada tanggal 20 September19 November 2018. Populasi dalam penelitian ini sebanyak 50 orang yang diambil berdasarkan data kunjungan pada bulan Juni-Agustus 2018.

Teknik pengambilan sampel
ditentukan dengan rumus Yamane/Slovin sehingga sampel yang digunakan dalam penelitian ini berjumlah 44 orang. Instrumen pada penelitian ini menggunakan kuesioner. Pada bagian awal instrumen penelitian berisi data karakteristik responden yang terdiri dari nama responden, umur, pendidikan, pekerjaan, dan alat kontrasepsi yang digunakan saat ini. Pada bagian kedua berisi variabel independen yaitu pengetahuan yang terdiri dari 10 pernyataan dengan nilai median 5, dukungan suami yang terdiri dari
5 pernyataan dengan nilai median 3 , dan peran petugas keluarga berencana (PLKB) terdiri dari 8 pernyataan dengan nilai median 4 dengan bobot jawaban jika benar maka skor 1 dan jika salah maka skor 0 .

Teknik analisa data yang digunakan pada penelitian ini yaitu analisa univariat dan analisa bivariat. Analisa univariat pada penelitian ini bertujuan untuk mendeskripsikan setiap variabel diantaranya pengetahuan, dukungan suami, dan peran PLKB. Sedangkan analisa bivariat dilakukan terhadap dua atau lebih variabel yang diduga memiliki korelasi, yaitu pengetahuan, dukungan suami, dan peran PLKB terhadap pemilihan metode kontrasepsi hormonal dengan menggunakan uji statistik Chi Square pada derajat kemaknaan 95\% $(\alpha \leq 0.05)$.

Etika penelitian dalam penelitian ini adalah yaitu hak untuk membuat keputusan secara sadar (Self Determination), hak untuk dihargai tentang apa yang mereka lakukan dan apa yang dilakukan terhadap mereka serta untuk mengontrol kapan dan bagaimana informasi tentang mereka dibagi dengan orang lain (privacy dan dignity), hak untuk dijaga kerahasiaan identitas dan informasi (anonymous dan confidentiality), hak terhadap penanganan yang adil, hak untuk mendapatkan perlindungan dari ketidaknyaman dan kerugian. (AIPVIKI, 2015)

\section{HASIL dan PEMBAHASAN}

\section{A. Karakteristik Responden}

Tabel 1. Distribusi frekuensi berdasarkan umur responden di Puskesmas Ranotana Weru Tahun 2018.

\begin{tabular}{ccc}
\hline Umur & $\mathrm{n}$ & $\mathbf{\%}$ \\
\hline$<20$ tahun & 4 & 9.1 \\
$20-35$ tahun & 28 & 63.6 \\
$>35$ tahun & 12 & 27.3 \\
\hline Total & 44 & 100.0 \\
\hline
\end{tabular}

Sumber : Data Primer, 2018

Berdasarkan tabel 1, menjelaskan bahwa dari 44 responden (100\%) didapati responden yang paling banyak menggunakan kontrasepsi hormonal yaitu 
pada rentang umur 20-35 tahun yaitu 28 responden $(63.6 \%)$ dan yang paling sedikit pada rentang usia $<20$ tahun yaitu sebanyak 4 responden $(9.15 \%)$.

Tabel 2. Distribusi frekuensi berdasarkan pendidikan responden di Puskesmas Ranotana Weru Tahun 2018.

\begin{tabular}{|c|c|c|}
\hline Pendidikan & $\mathrm{n}$ & $\%$ \\
\hline SD & 3 & 6.8 \\
\hline SLTP & 13 & 29.5 \\
\hline SLTA & 20 & 45.5 \\
\hline Akademik/PT & 8 & 18.2 \\
\hline Total & 44 & 100.0 \\
\hline
\end{tabular}

Berdasarkan tabel 2, menjelaskan bahwa dari 44 responden (100\%) didapati pendidikan terbanyak responden yang menggunakan kontrasepsi hormonal adalah SLTA sebanyak 20 responden $(45.5 \%)$ dan terendah adalah SD sebanyak 3 responden $(6.8 \%)$.

Tabel 3. Distribusi frekuensi berdasarkan pekerjaan responden di Puskesmas Ranotana Weru Tahun 2018.

\begin{tabular}{ccc}
\hline Pekerjaan & $\mathrm{n}$ & $\%$ \\
\hline Wiraswasta & 5 & 11.4 \\
Pegawai & 6 & 13.6 \\
negeri/swasta & & \\
IRT & 33 & 75.0 \\
\hline Total & 44 & 100.0
\end{tabular}

Sumber : Data Primer, 2018

Berdasarkan tabel 3, menjelaskan bahwa dari 44 responden $(100 \%)$ dominan pekerjaan adalah ibu rumah tangga yaitu sebanyak 33 responden $(75.0 \%)$ dan yang paling sedikit adalah wiraswasta sebanyak 5 responden $(11.4 \%)$.
Tabel 4. Distribusi frekuensi berdasarkan alat kontrasepsi yang digunakan saat ini di Puskesmas Ranotana Weru Tahun 2018.

\begin{tabular}{ccc}
\hline $\begin{array}{c}\text { Alat kontrasepsi yang } \\
\text { digunakan saat ini }\end{array}$ & $\mathrm{n}$ & $\%$ \\
\hline Pil & 8 & 18.2 \\
Suntik & 28 & 63.6 \\
Implan & 8 & 18.2 \\
\hline Total & 44 & 100.0 \\
\hline
\end{tabular}

Sumber : Data Primer, 2018

Berdasarkan tabel 4, menjelaskan bahwa dari 44 responden $(100 \%)$ yang terbanyak dalam penggunaan kontrasepsi hormonal adalah jenis suntik yaitu sebanyak 28 responden (63.6\%) dan yang paling sedikit adalah jenis pil dan implan yang masing-masing sebanyak 8 responden $(18.2 \%)$.

\section{B. Analisa Univariat}

Tabel 5. Distribusi frekuensi berdasarkan pengetahuan responden di Puskesmas Ranotana Weru Tahun 2018.

\begin{tabular}{ccc}
\hline Pengetahuan & $\mathrm{n}$ & $\%$ \\
\hline Baik & 36 & 81.8 \\
Kurang & 8 & 18.2 \\
\hline Total & 44 & 100.0 \\
\hline
\end{tabular}

Sumber : Data Primer, 2018

Berdasarkan tabel 5, didapati dari 44 responden (100\%), terdapat 36 responden $(81.8 \%)$ memiliki pengetahuan baik, dan 8 responden (18.2\%) memiliki pengetahuan kurang. Pengetahuan dikatakan baik jika responden memperoleh skor jawaban $\geq$ nilai median dari 10 pertanyaan yang diajukan. Dan pengetahuan dikatakan kurang jika responden memperoleh skor jawaban < nilai median dari 10 pertanyaan yang diajukan. 
Tabel 6. Distribusi frekuensi berdasarkan dukungan suami responden di Puskesmas Ranotana Weru Tahun 2018.

\begin{tabular}{ccc}
\hline Dukungan Suami & $\mathrm{n}$ & $\%$ \\
\hline Mendukung & 29 & 65.9 \\
Tidak Mendukung & 15 & 34.1 \\
\hline Total & 44 & 100.0 \\
\hline
\end{tabular}

Sumber : Data Primer, 2018

Berdasarkan tabel 6, dari 44 responden $(100 \%)$ didapati sebanyak 29 responden $(65.9 \%)$ suami mendukung akseptor $\mathrm{KB}$, dan 15 responden $(34.1 \%)$ suami tidak mendukung akseptor KB. Dukungan suami dikategorikan dengan mendukung jika responden memperoleh skor jawaban $\geq$ nilai median dari 5 pertanyaan yang diajukan. Dan tidak mendukung jika responden memperoleh skor jawaban < nilai median dari 5 pertanyaan yang diajukan.

Tabel 7. Distribusi frekuensi berdasarkan peran PLKB responden di Puskesmas Ranotana Weru Tahun 2018.

\begin{tabular}{ccc}
\hline Peran PLKB & $\mathrm{n}$ & $\%$ \\
\hline Berperan & 20 & 45.5 \\
Tidak Berperan & 24 & 54.5 \\
\hline Total & 44 & 100.0
\end{tabular}

Sumber : Data Primer, 2018

Berdasarkan tabel 7, didapati dari 44 responden (100\%) sebanyak 20 responden $(45.5 \%)$ berperan sedangkan 24 responden $(54.5 \%)$ tidak berperan terhadap pemilihan metode kontrasepsi hormonal. Peran PLKB dikategorikan dengan berperan jika responden memperoleh skor jawaban $\geq$ nilai median dari 8 pertanyaan yang diajukan. Dan tidak berperan jika responden memperoleh skor jawaban < nilai median dari 8 pertanyaan yang diajukan.
Tabel 8. Distribusi frekuensi berdasarkan pemilihan metode kontrasepsi hormonal di Puskesmas Ranotana Weru Tahun 2018.

\begin{tabular}{ccc}
\hline $\begin{array}{c}\text { Pemilihan metode } \\
\text { kontrasepsi hormonal }\end{array}$ & $\mathrm{n}$ & $\%$ \\
\hline Pil & 8 & 18.2 \\
Suntik & 28 & 63.6 \\
Implan & 8 & 18.2 \\
\hline Total & 44 & 100.0
\end{tabular}

Sumber : Data Primer, 2018

Berdasarkan tabel 8, menjelaskan bahwa dari 44 responden $(100 \%)$ yang memilih metode kontrasepsi hormonal, sebanyak 8 responden memilih kontrasepsi pil $(18.2 \%), 28$ responden yang memilih kontrasepsi suntik (63.6\%), dan 8 responden yang memilih kontrasepsi implan (18.2\%). Menurut Rusmini (2016), kontrasepsi hormonal adalah alat kontrasepsi yang berisi hormon yang terdiri dari kontrasepsi pil, suntik, dan implan. Pil $\mathrm{KB}$ adalah kontrasepsi yang berbentuk pil atau tablet yang harus diminum setiap hari. Kontrasepsi suntik adalah jenis kontrasepsi yang digunakan dengan cara menyuntikan secara intramuscular setiap 1 atau 3 bulan. Sedangkan kontrasepsi implan yaitu jenis kontrasepsi yang diinsersikan pada bagian subdermal yang di masukkan di lengan atas sehingga tidak terjadi kehamilan. (Rusmini et al , 2016).

\section{Analisa Bivariat}

Tabel 9. Tabulasi silang hubungan pengetahuan dengan pemilihan metode kontrasepsi hormonal pada wanita usia subur di wilayah kerja Puskesmas Ranotana Weru.

\begin{tabular}{|c|c|c|c|c|c|c|c|c|c|}
\hline \multirow{3}{*}{ Pengetahuan } & \multicolumn{6}{|c|}{$\begin{array}{c}\text { Metode Kontrasepsi } \\
\text { Hormonal }\end{array}$} & \multirow{2}{*}{\multicolumn{2}{|c|}{ Total }} & \multirow{3}{*}{$p$ value } \\
\hline & \multicolumn{2}{|r|}{ Pil } & \multicolumn{2}{|c|}{ Suntik } & \multicolumn{2}{|c|}{ Implan } & & & \\
\hline & n & $\%$ & n & $\%$ & $\mathbf{n}$ & $\%$ & $\mathbf{n}$ & $\%$ & \\
\hline Baik & 4 & 11.1 & 25 & 69.4 & 7 & 19.4 & 36 & 100 & 0.036 \\
\hline Kurang & 4 & 50.0 & 3 & 37.5 & 1 & 12.5 & 8 & 100 & \\
\hline Total & 8 & 18.2 & 28 & 63.6 & 8 & 18.2 & 44 & 100 & \\
\hline
\end{tabular}

Berdasarkan tabel 9, diketahui responden yang memiliki pengetahuan baik 
dan memilih kontrasepsi pil sebanyak 4 responden (11.1\%), responden yang memiliki pengetahuan baik dan memilih kontrasepsi suntik sebanyak 25 responden $(69.4 \%)$, dan responden yang memiliki pengetahuan baik dan memilih kontrasepsi implan sebanyak 7 responden (19.4\%). Sedangkan responden dengan pengetahuan kurang dan memilih kontrasepsi pil sebanyak 4 responden $(50.0 \%)$, responden yang memiliki pengetahuan kurang dan memilih kontrasepsi implan sebanyak 3 responden $(37.5 \%)$, dan responden yang memiliki pengetahuan kurang dan memilih kontrasepsi implan sebanyak 1 responden $(12.5 \%)$. Hasil uji statistik diperoleh nilai $p=0.036$ atau nilai $p<\alpha$ atau 0.05 . Dengan demikian, maka $\mathrm{H}_{0}$ ditolak dan $\mathrm{H}_{\mathrm{a}}$ diterima. Hal ini menunjukkan bahwa ada hubungan pengetahuan dengan pemilihan metode kontrasepsi hormonal pada wanita usia subur di wilayah kerja Puskesmas Ranotana Weru.

Tabel 10. Tabulasi silang hubungan dukungan suami dengan pemilihan metode kontrasepsi hormonal pada wanita usia subur di wilayah kerja Puskesmas Ranotana Weru.

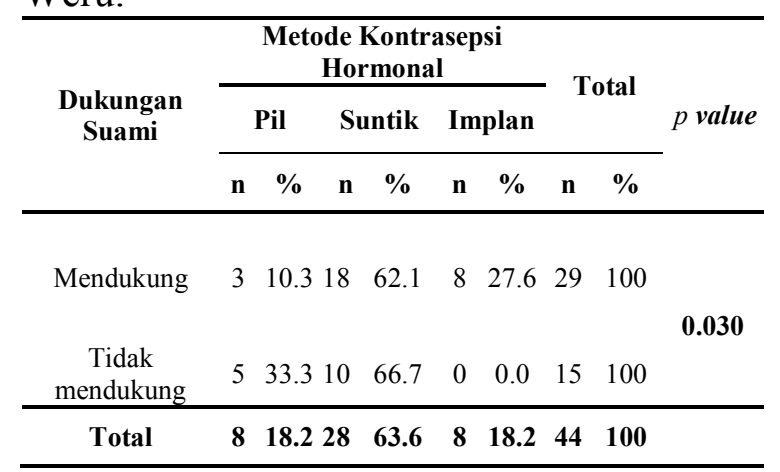

Sumber : Data Primer, 2018

Berdasarkan tabel 10, diketahui
bahwa responden yang memilih
kontraspepsi pil dan mengatakan ada
dukungan suami sebanyak 3 responden
$(10.3 \%)$, responden dengan kontrasepsi
suntik dan mengatakan ada dukungan suami
sebanyak 18 responden $(62.1 \%)$, dan
responden dengan kontrasepsi implan dan
mengatakan ada dukungan suami sebanyak
8 responden $(26.7 \%)$. Sedangkan responden yang memilih kontrasepsi pil dan mengatakan tidak ada dukungan suami sebanyak 5 responden (33.3\%), responden dengan kontrasepsi suntik dan mengatakan tidak ada dukungan suami sebanyak 10 responden $(66.7 \%)$, dan responden dengan kontrasepsi implan dan mengatakan ada dukungan suami sebanyak 0 responden $(0.0 \%)$. Hasil uji statistik Chi Square diperoleh nilai $p=0.030$ atau nilai $p<\alpha$ atau 0.05 . Dengan demikian, maka $\mathrm{H}_{0}$ ditolak dan $\mathrm{H}_{\mathrm{a}}$ diterima. Hal ini menunjukkan bahwa ada hubungan dukungan suami dengan pemilihan metode kontrasepsi hormonal pada wanita usia subur di wilayah kerja Puskesmas Ranotana Weru.

Tabel 11. Tabulasi silang hubungan peran PLKB dengan pemilihan metode kontrasepsi hormonal pada wanita usia subur di wilayah kerja Puskesmas Ranotana Weru.

\begin{tabular}{|c|c|c|c|c|c|c|c|c|c|}
\hline \multirow{3}{*}{ Peran PLKB } & \multicolumn{6}{|c|}{$\begin{array}{c}\text { Metode Kontrasepsi } \\
\text { Hormonal }\end{array}$} & \multirow{2}{*}{\multicolumn{2}{|c|}{ Total }} & \multirow{3}{*}{$\begin{array}{c}p \\
\text { value }\end{array}$} \\
\hline & \multicolumn{2}{|r|}{ Pil } & \multicolumn{2}{|c|}{ Suntik } & \multicolumn{2}{|c|}{ Implan } & & & \\
\hline & $\mathbf{n}$ & $\%$ & n & $\%$ & $\mathbf{n}$ & $\%$ & n & $\%$ & \\
\hline Berperan & 3 & 15.0 & 15 & 75.0 & 2 & 10.0 & 20 & 100 & \\
\hline Tidak Berperan & 5 & 20.8 & 13 & 54.2 & 6 & 25.0 & 24 & 100 & 0.317 \\
\hline Total & 8 & 18.2 & 28 & 63.6 & 8 & 18.2 & 44 & 100 & \\
\hline
\end{tabular}

Sumber : Data Primer, 2018

Berdasarkan tabel 11, diketahui responden yang memilih kontraspepsi pil dan mengatakan ada peran PLKB sebanyak 3 responden $(15.0 \%)$, responden dengan kontrasepsi suntik dan mengatakan ada peran PLKB sebanyak 15 responden (75.0\%), dan responden dengan kontrasepsi implan dan mengatakan ada peran PLKB sebanyak 2 responden (10.0\%). Sedangkan responden yang memilih kontraspepsi pil dan mengatakan tidak ada peran PLKB sebanyak 5 responden (20.8\%), responden dengan kontrasepsi suntik dan mengatakan tidak ada peran PLKB sebanyak 13 responden $(54.2 \%)$, dan responden dengan kontrasepsi implan dan mengatakan tidak ada peran PLKB sebanyak 6 responden (25.0\%). Hasil uji statistik Chi Square 
diperoleh nilai $p=0.317$ atau nilai $p>\alpha$ atau 0.05. Dengan demikian, maka $\mathrm{H}_{0}$ gagal ditolak. Hal ini menunjukkan bahwa tidak ada hubungan peran PLKB dengan pemilihan metode kontrasepsi hormonal pada wanita usia subur di wilayah kerja Puskesmas Ranotana Weru.

\section{A. Karakteristik Responden \\ 1. Umur}

Hasil penelitian ini sejalan dengan penelitian yang dilakukan Musdalifah (2013) yang menunjukkan bahwa berdasarkan umur responden, distribusi tertinggi berada pada umur 20-24 tahun. Hal ini dikarenakan pada umur 20-35 tahun adalah usia produktif yang mengharuskan wanita agar dapat merencanakan dengan baik jumlah anak yang diinginkan.

\section{Pendidikan}

Hasil penelitian ini sejalan dengan hasil penelitian yang dilakukan oleh Tambak (2013), yang menunjukkan bahwa responden terbanyak yang menggunakan kontrasepsi berada pada tingkat pendidikan SMA. Hal ini dikarenakan status pendidikan terbanyak yang ada di wilayah kerja Puskesmas Ranotana Weru adalah sekolah menengah atas (SMA atau SLTA) yaitu $34.9 \%$.

\section{Pekerjaan}

Hasil penelitian ini sejalan dengan penelitian yang dilakukan oleh Rizali (2013) yang mengatakan bahwa dilihat dari tingkat pekerjaan, responden yang menggunakan KB terbanyak bekerja sebagai ibu rumah tangga (79.8\%). Hal ini dikarenakan sebagian besar pekerjaan wanita di wilayah kerja Puskesmas Ranotana Weru adalah sebagai ibu rumah tangga.

\section{Alat Kontrasepsi yang digunakan saat ini}

Hasil penelitian menjelaskan bahwa mayoritas pengguna kontrasepsi adalah pengguna KB suntik. Hasil penelitian ini sejalan dengan penelitian yang dilakukan oleh Awalia (2013) yang menjelaskan bahwa sebagian besar responden memilih jenis kontrasepsi suntik sebanyak 28 responden (59.6\%). Hal ini dikarenakan berdasarkan data di wilayah kerja Puskesmas Ranotana Weru tercatat sebanyak 2772 orang menggunakan KB suntik aktif dan 223 orang yang merupakan KB suntik baru dari total 3761 wania usia subur.

\section{B. Analisa Univariat \\ 1. Pengetahuan}

Hasil penelitian ini sejalan dengan penelitian yang dilakukan oleh Rizali (2013) yang mengatakan bahwa dari 193 responden yang memiliki pengetahuan cukup sebanyak 134 responden (69.4\%) dan yang memiliki pengetahuan kurang sebanyak 59 responden $(30.6 \%)$.

Ditinjau berdasarkan tingkat pendidikan, didapatkan sebanyak 20 responden berpendidikan SLTA dan 8 responden yang berpendidikan di Perguruan Tinggi, hal ini membuktikan bahwa tingkat pendidikan responden berada pada tingkat pendidikan yang baik. Selain itu, responden yang menjadi sampel dalam penelitian ini kebanyakan adalah akseptor $\mathrm{KB}$ aktif sehingga sudah sering terpapar dengan informasi mengenai KB.

\section{Dukungan Suami}

Hasil penelitian ini sejalan dengan penelitian yang dilakukan oleh Arliana (2013) yang mengatakan bahwa dari 133 responden sebagian besar responden mendapat dukungan dari suami (97.2\%). Hal ini dikarenakan sebagian besar pengambilan keputusan mengikuti program $\mathrm{KB}$ atas kesepakatan bersama, sehingga selama mengikuti program suami turut berpartisipasi dalam hal membiayai alat kontrasepsi yang akan digunakan.

\section{Peran PLKB}

Hasil penelitian ini sejalan dengan penelitian yang dilakukan Samosir (2016) yang menjelaskan bahwa sebagian besar responden mengatakan petugas kurang berperan dalam program Keluarga Berencana. Hal ini buktikan dari banyaknya akseptor yang mengaku belum pernah mengikuti penyuluhan atau sosialisasi tentang program $\mathrm{KB}$ sehingga pemilihan 
KB hanya berdasar atas keinginan pribadi tanpa alasan yang mantap.

\section{Pemilihan metode kontrasepsi hormonal}

Hasil penelitian yang dilakukan oleh Irmawati (2012) dari 76 responden, sebanyak 73 responden (96.1\%) menggunakan metode kontrasepsi hormonal. Hal ini karena kontrasepsi suntik yang dianggap aman dan praktis, selain itu memiliki efektivitas tinggi dengan tingkat keberhasilan 99\%, dan keuntungan lain untuk suntikan 3 bulan yaitu tidak mempengaruhi ASI dan cocok untuk ibu menyusui.

\section{Analisa Bivariat}

1. Hubungan pengetahuan dengan pemilihan metode kontrasepsi hormonal pada wanita usia subur di wilayah kerja Puskesmas Ranotana Weru.

Hal penelitian ini sejalan dengan penelitian yang dilakukan Novita Lusiana (2017) yang mengatakan ada hubungan pengetahuan dengan pemilihan alat alat kontrasepsi hormonal. Hal ini dikarenakan jumlah akseptor KB suntik di wilayah kerja Puskesmas Ranotana Weru lebih banyak dengan tingkat pendidikan yang rata-rata berada pada tingkat pendidikan tinggi. Selain itu, akseptor KB yang ada di wilayah kerja Puskesmas Ranotana Weru merupakan akseptor KB aktif yang sudah sering terpapar informasi mengenai $\mathrm{KB}$. Akseptor yang memilih menggunakan implan adalah akseptor KB yang aktif yang sebelumnya pernah menggunakan KB suntik dan pil.

Alasan memilih KB implan agar akseptor tidak perlu selalu kembali ke tempat pelayanan karena jangka waktu penggunaan implan yang relatif lebih lama dibandingkan suntik dan pil. Sedangkan responden yang memiliki pengetahuan kurang adalah responden yang memilih kontrasepsi pil, hal ini dikarenakan responden tersebut merupakan akseptor baru yang masih begitu asing terhadap program KB.
Peneliti berasumsi, adanya hubungan antara pengetahuan dengan pemilihan metode kontrasepsi hormonal karena sebagian besar responden yang memiliki pengetahuan baik tentang kontrasepsi hormonal sehingga keputusan yang diambil berdasar atas keputusan yang rasional. Hal ini dibuktikan dengan distribusi umur responden yang memilih kontrasepsi hormonal tertinggi berada pada umur 20-35 tahun sehingga telah sesuai dengan tujuan penggunaan kontrasepsi dimana pada fase umur 20-35 tahun dianjurkan agar dapat menjarangkan kehamilan dengan jenis kontrasepsi yang dianjurkan seperti IUD, pil, dan suntik.

2. Hubungan dukungan suami dengan pemilihan metode kontrasepsi hormonal pada wanita usia subur di wilayah kerja Puskesmas Ranotana Weru.

Hasil penelitian ini sejalan dengan penelitian yang dilakukan oleh Wa Ode Dita Arlina (2013) yang mengatakan ada hubungan antara dukungan suami dengan pemilihan metode kontrasepsi hormonal. Hal ini dikarenakan jangka waktu penggunaan suntik dan implan yang lebih lama dibandingkan pil. Sehingga suami tidak perlu takut jika istri akan hamil lagi. Sebaliknya suami yang tidak mendukung diketahui lebih banyak pada responden yang menggunakan pil, dikarenakan para suami beranggapan kadang-kadang istri sering lupa sehingga program $\mathrm{KB}$ dinilai tidak berhasil.

Peneliti berasumsi, ada hubungan dukungan suami dengan pemilihan metode kontrasepsi hormonal karena suami sudah paham pentingnya program keluarga berencana demi membentuk suatu keluarga sehat sejahtera.

3. Hubungan peran PLKB dengan pemilihan metode kontrasepsi hormonal pada wanita usia subur di wilayah kerja Puskesmas Ranotana

Berdasarkan hasil penelitian didapati mayoritas responden mengatakan tidak ada peran PLKB. Hal ini dibuktikan dari banyaknya responden di wilayah kerja 
Puskesmas Ranotana Weru mengatakan belum pernah mengikuti penyuluhan tentang Keluarga Berencana pada saat pertama kali akan menggunakan alat kontrasepsi.

Hasil penelitian ini tidak sejalan dengan penelitian oleh Supriadi yang mengatakan ada hubungan antara peran PLKB dengan penggunaan alat kontrasepsi. Peneliti berasumsi, tidak ada hubungan peran PLKB dengan pemilihan metode kontrasepsi hormonal dikarenakan kelompok akseptor KB yang datang adalah kelompok akseptor yang menjalani program keluarga berencana ulangan. Selain itu, di Puskesmas Ranotana Weru sudah terpampang poster-poster mengenai alat-alat kontrasepsi hormonal sehingga peran petugas dalam memberikan sosialisasi secara berkala lebih diminimalkan.

\section{SIMPULAN}

1. Ada hubungan antara pengetahuan dengan pemilihan metode kontrasepsi hormonal pada wanita usia subur di wilayah kerja Puskesmas Ranotana Weru.

2. Ada hubungan antara dukungan suami dengan pemilihan metode kontrasepsi hormonal pada wanita usia subur di wilayah kerja Puskesmas Ranotana Weru.

3. Tidak ada hubungan peran PLKB dengan pemilihan metode kontrasepsi hormonal pada wanita usia subur di wilayah kerja Puskesmas Ranotana Weru.

\section{DAFTAR PUSTAKA}

AIPVIKI. (2015). Pedoman Penulisan Karya Tulis Ilmiah Keperawatan. Jakarta: AIPVIKI

Arliana, Waode Dita. (2013). Faktor yang berhubungan dengan penggunaan metode kontrasepsi hormonal pada akseptor KB di Kelurahan Pasarwajo Kecamatan Pasarwajo Kabupaten Buton Sulawesi Tenggara. Jurnal Kesehatan Masyarakat. Fakultas
Kesehatan Masyarakat Universitas Hasanuddin Makassar. Di unduh di http://repositori.unhas.ac.id pada tanggal 05/11/2018 pukul 23:22 Wita.

Awalia, Isma Ginta. (2013). Faktor-faktor yang berhubungan dengan perilaku pemilihan jenis kontrasepsi hormonal di desa Kemurang Wetan Kecamatan Tanjung Kabupaten Brebes Tahun 2013. Jurnal Kebidanan. Politeknik Harapan Bersama Tegal. Diunduh di http://ejournal.poltektegal.ac.id pada tanggal 19/11/2018 pukul 09:14 Wita.

Badan Pusat Statistik Indonesia. (2017). Proyeksi penduduk Indonesia Berdasarkan Hasil Sensus Penduduk 2010-2035. Di unduh di www.bps.go.id/; September 10, Jam 20:05 Wita

Badan Pusat Statistik Sulawesi Utara. (2016-2017). Proyeksi penduduk Indonesia Berdasarkan Hasil Sensus Penduduk 2010-2035. Diunduh di http://sulut.bps.go.id September 10, Jam 20:05 Wita

Hartanto, H. (2010). Keluarga Berencana dan Kontrasepsi. Jakarta: Pustaka sinar harapan.

Irianto, Koes. (2014). Pelayanan Keluarga Berencana. Bandung: Alfabeta.

Irmawati. (2012). Faktor-faktor yang mempengaruhi penggunaan alat kontrasepsi hormonal pada akseptor KB di Puskesmas Samata Kel. Romang Polong Kecamatan Sombo Opu Kabupaten Gowa 2012. Jurnal Keperawatan. Fakultas Ilmu Kesehatan Universitas Islam Negeri Alauddin Makassar. Diunduh di http://repositori.uin-alauddin.ac.id pada tanggal 20/09/2018 pukul 15:19 Wita.

Lusiana, Novita. (2017). Faktor-faktor yang mempengaruhi wanita usia subur dalam pemilihan alat kontrasepsi hormonal di BPM Sri Maya Tresia, 
SST.. Jurnal Kebidanan; Program Studi D-III Kebidanan STIKes Hang Tuah Pekanbaru. Vol. XI Jilid 1 No. 75 April 2017. Di unduh di http://jurnal.umsb.ac.id/index.php/men arailmu/article/view/155/135 pada tanggal 27/09/2018 pukul 21:03 Wita

Mardiansyah. (2014). Faktor yang berhubungan dengan penggunaan alat kontrasepsi pada pasutri di Kelurahan Tamalanrea Indah Kota Makassar. Jurnal Kesehatan Masyarakat. Fakultas Kesehatan Masyarakat Universitas Hasanuddin Makassar. Di unduh di http://repositori.unhas.ac.id pada tanggal $05 / 11 / 2018$ pukul 23:30 Wita.

Musdalifah. (2013). Faktor-faktor yang berhubungan dengan pemilihan kontrasepsi hormonal pasutri di wilayah kerja Puskesmas Lampa Kecamatan Duampanua Kabupaten Pinrang 2013. Jurnal Kesehatan Masyarakat. Fakultas Kesehatan Masyarakat Universitas Hasanuddin Makassar. Di unduh di http://repository.unhas.ac.id/handle/12345 6789/5657 pada tanggal 27/09/2018 pukul 21:10 Wita.

Profil Puskesmas Ranotana Weru. (2018).

Data Kunjungan Akseptor KB Puskesmas Ranotana Weru Tahun 2018. Diunduh di www.bankdata.depkes.go.id pada tanggal 18/12/2018 pukul 11:54 Wita.

Rizali, Muhammad Irwan. (2013). Faktor yang berhubungan dengan pemilihan metode kontrasepsi suntik di Kelurahan Mattoangin Kecamatan Mariso Kota Makassar. Jurnal Kesehatan Masyarakat. Fakultas Kesehatan Masyarakat Universitas Hasanuddin Makassar. Di unduh di http://media.neliti.com-publications pada tanggal 03/11/2018 pukul 19:10 Wita.

Rusmini, Septerina, P, Vina, U., \& Sitti, F. (2016). Pelayanan KB dan
Kesehatan Reproduksi Berbasis Evidence Based. Jakarta: CV. Trans Info Media.

Samosir, Okta Nidya Boro. (2016). Hubungan peran petugas dan pengalaman $\mathrm{KB}$ dengan pergantian metode KB di Kecamatan Tembalang Kota Semarang Triwulan II Tahun 2016. Jurnal Kesehatan Masyarakat Volume 4, Nomor 4, Oktober 2016 (ISSN:2356-3346). Fakultas Kesehatan Masyarakat Universitas Diponegoro. Diunduh di http://ejounals1.undip.ac.id/index.php/jkm pada tanggal 04/12/2018 pukul 20:39 Wita.

Siswanto, Susila, \& Suyanto. (2016). Metode Penelitian Kesehatan dan Kedokteran. Yogyakarta: Bursa Ilmu.

Supriadi. (2017). Faktor yang berhubungan dengan penggunaan alat kontrasepsi pada pasangan usia subur di wilayah kerja Puskesmas Kapasa. Skripsi diterbitkan. Makassar: Fakultas Kesehatan Masyarakat Universitas Hasanuddin. Diunduh di http://digilib.unhas.ac.id/opac/ pada tanggal 03/11/2018 pukul 14:20 Wita.

Susenas. (2015). Analisa Data Kependudukan dan KB Hasil Susenas. http://kalbar.bkkbn.go.id/SiteCollectio nDocuments/Analisis\%20Data\%20Ke pendudukan $\% 20$ dan $\% 20 \mathrm{~KB} \% 20 \mathrm{Hasil}$ $\% 20$ Susenas $\% 202015$. pdf?Mobile $=1$; September 11, 2018; Jam 23:06 Wita.

Tambak, Dewintha (2013). Analisa faktorfaktor yang mempengaruhi pemilihan Metode kontrasepsi pada pasangan usia subur (pus) di Wilayah Kerja Puskesmas Pancur Batu. Skripsi diterbitkan. Fakultas Keperawatan Universitas Sumatera Utara. Diunduh di http://repository.usu.ac.id pada tanggal 17/10/2018 pukul 17:02 Wita. 